\title{
Mental health care technologies: Primary Care practices and processes
}

\author{
Tecnologias do cuidado em saúde mental: práticas e processos da Atenção Primária \\ Tecnologías del cuidado en salud mental: prácticas y procesos de la Atención Primaria
}

\author{
Daniella Barbosa Campos', Indara Cavalcante Bezerra", Maria Salete Bessa Jorge' \\ ' Universidade Estadual do Ceará. Fortaleza, Ceará, Brazil. \\ "Universidade de Fortaleza. Fortaleza, Ceará, Brazil.
}

\section{How to cite this article:}

Campos DB, Bezerra IC, Jorge MSB. Mental health care technologies: Primary Care practices and processes. Rev Bras Enferm [Internet]. 2018;71(Suppl 5):2101-8. [Thematic Issue: Mental health] DOI: http://dx.doi.org/10.1590/0034-7167-2017-0478

Submission: 06-30-2017 Approval: 10-01-2017

\begin{abstract}
Objective: To analyze the technologies of mental health care used in the practices and processes that constitute Primary Health Care from the discourses of nurses of the Family Health Strategy. Method: Qualitative approach based on the dialectical hermeneutic composition which aims to perform a comprehensive and critical analysis of semi-structured interviews, and free field observation. Results: From the empirical material analyzed, two essential analytical categories emerged: "Health technologies used in PHC for the care of users with psychological distress" and "To stop medicating suffering and to Train professionals". Final considerations: The study pointed the reception and matrixing as the main technologies of care exercised in the interface of Primary Health Care with Mental Health. However, there was a need for reinforcing actions for matrixing, for training in order to improve the professionals' autonomy in face of this demand, as well as the importance of stop medicating individuals with psychological distress.
\end{abstract}

Descriptors: Comprehensive Health Care; Mental Health; Primary Health Care; Technology; Nursing.

\section{RESUMO}

Objetivo: Analisar as tecnologias do cuidado em saúde mental utilizadas nas práticas e processos constituintes da Atenção Primária à Saúde a partir dos discursos de enfermeiros da Estratégia Saúde da Família. Método: Abordagem qualitativa fundamentada na composição hermenêutica dialética a qual visa realizar uma análise compreensiva e crítica de entrevistas semiestruturadas, e observação livre do campo. Resultados: Do material empírico analisado, emergiram duas categorias analíticas essenciais: "Tecnologias em saúde utilizadas na APS para o atendimento aos usuários em sofrimento psíquico" e "Desmedicamentalizar o sofrimento e Capacitar os profissionais". Considerações finais: $\mathrm{O}$ estudo apontou o acolhimento e o matriciamento como as principais tecnologias de cuidado exercidas na interface da Atenção Primária à Saúde com a Saúde Mental. Entretanto, evidenciouse a necessidade de ações fortalecedoras para o matriciamento, para a capacitação no sentido de melhorar a autonomia dos profissionais diante dessa demanda, além da importância da desmedicamentalização dos sujeitos em sofrimento psíquico.

Descritores: Assistência Integral à Saúde; Saúde Mental; Atenção Primária à Saúde; Tecnologia; Enfermagem.

\section{RESUMEN}

Objetivo: Análisis de las tecnologías del cuidado en salud mental utilizadas en las prácticas y procesos constituyentes de la Atención Primaria a la Salud a partir de los discursos de enfermeros de la Estrategia Salud de la Familia. Método: Enfoque cualitativo fundamentado en la composición hermenéutica dialéctica la cual busca realizar un análisis comprensivo y crítico de entrevistas semiestructuradas, y observación libre del campo. Resultados: En el material empírico analizado, surgieron dos categorías analíticas esenciales: "Tecnologías en salud utilizadas en la APS para la atención a los usuarios en sufrimiento psíquico" y "Desmedicamentalizar el sufrimiento y Capacitar a los profesionales". Consideraciones finales: El estudio apuntó la acogida y el matriciamiento como las principales tecnologías de cuidado ejercidas en la interfaz de la Atención Primaria a la Salud con la Salud Mental. Sin embargo, se evidenció la necesidad de acciones fortalecedoras para el matriciamiento, para la 
capacitación en el sentido de mejorar la autonomía de los profesionales frente a esa demanda, además de la importancia de la desmedicamentalización de los sujetos en sufrimiento psíquico.

Descriptores: Atención Integral de Salud; Salud Mental; Atención Primaria de Salud; Tecnología; Enfermería.

\section{CORRESPONDING AUTHOR}

\section{Daniella Barbosa Campos}

E-mail: dane_barbosa@hotmail.com

\section{INTRODUCTION}

Mental health care in the context of Primary Health Care (PHC) should include the use of technologies based on the real needs of users to promote efficient and quality care. However, with regard to the practices and processes that constitute primary care, complex challenges persist, ranging from training processes to communication between people, services and care networks. This article intends to reflect on the interface of mental health in the context of PHC.

$\mathrm{PHC}$, as the caregiver and mainstreamer of health care practices, is confronted daily with problems arising from psychological distress. According to the Ministry of Health, psychiatric complaints are the second cause of demand for care in PHC services by the population ${ }^{(1)}$. In this context, in 2008, the World Health Organization (WHO) pointed out the importance of comprehension of mental health actions in Primary Health Care, by recommending to the territory, the community and the health services networks, to organize themselves in order to recognize that Mental Health Care is part of primary health care, with emphasis on new forms of care $^{(2)}$.

Thus, $\mathrm{PHC}$ plays a fundamental role in the restructuring and reorganization of health services, which can increase access to mental health for a greater number of users and reduce referrals from patients with less severe conditions to specialized care $^{(3)}$. The health professional at the basic level of attention has the possibility to know better the reality of the user by the proximity to the territory of social life, which enhances a more resolute and comprehensive action.

In the practical field, the Brazilian Unified Health System (SUS- Sistema Único de Saúde) has emphasized for PHC actions aimed at a care based on soft technologies, such as reception, horizontal and longitudinal monitoring of users, strengthening of autonomy and focus on subjectivity, as well as , encouraging participation in community activities and support groups ${ }^{(4)}$.

The incorporation of these technologies can modify the way of living and influencing the social, economic and environmental fields. Thus, the introduction of the technologies in the assistance settings becomes relevant, since it implies in the redimensioning of care spaces ${ }^{(5)}$.

The Ministry of Health considers health technologies as medicines, equipment and procedures, organizational, educational, information and support systems, as well as health care programs and protocols through which health care is provided to the population ${ }^{(6)}$. Law 12.401, of April 28, 2011, advances in this concept, providing on the therapeutic assistance and the incorporation of technology in health within the SUS.

In parallel to this process, authors like Merhy and Feuerwerker $^{(7)}$ use an analogy with the toolbox to classify three types of technology: the 'hard', linked to the propaedeutics and to the procedures (diagnostic and therapeutic), the which requires the use of machinery and its operators; the 'soft and hard', characterized by scientific knowledge (such as Clinical and Epidemiology) and mediated by clinical reasoning, such as doctor-user interaction in services; the third technology refers to the 'soft', whose focus is between the worker and the user, in the production of their relations.

In order for the actions in the mental health work process to be efficient, it is necessary to adopt soft technologies, such as reception, bonding and comprehensive care ${ }^{(8)}$. At PHC, interventions should include various technologies in accordance with user needs and availability of health services, with a view to improving their living conditions to the detriment of care, which requires material technologies ${ }^{(8)}$.

The guarantee of quality and effectiveness of care should, as a starting point, consider the needs of users, establish links, be responsible and welcome. It is in this micropolitical environment that the purpose of health work occurs; in the environment of intersubjectivity and in the relationships in which professionals use all available technologies to achieve the essential objective: to meet the user's health needs ${ }^{(9)}$.

Thus, the international literature points out that the use of PHC care technologies has the potential to improve access and quality of mental health care. In a study produced in the United States, it was observed that primary care has assumed an increasingly important role in outpatient care, through the formation of links between professionals and users, playing a vital role in caring for this population ${ }^{(10)}$. In Norway, the Ruud et al. ${ }^{(11)}$ study compared the satisfaction of users with psychiatric problems receiving PHC care and Hospital services, and realized that there is greater satisfaction among users who are assisted by Primary Care due to the use of technologies of care that respect the subjectivity and the singularity of each.

Brazilian studies ${ }^{(12-13)}$ recognize that the practices developed through the use of mild PHC technologies in the field of mental health value the dimension of subjectivity, improving the quality of care. However, other research shows that there is fragility in the articulation between PHC and CAPS services, according to Onocko-Campos et al. ${ }^{(14)}$, on the fragmentation of the network, where many cases are lost in an institutional entanglement. Hirdes and Scarparo ${ }^{(15)}$ portray that $\mathrm{PHC}^{\prime}$ s articulation with specialized services is still incipient in municipalities, favoring the fragmentation of care. Jorge et al. ${ }^{(16)}$ portray that the fragile articulation of the health services makes difficult the problemsolving of the psychosocial attention. For Campos et al. ${ }^{(17)}$, this reality is aggravated by the lack of technical preparation of the professional, the precarious working conditions, the lack of investment of the managers, the absence of qualified listening in the PHC, among other aspects that hinder a appropriate response to mental health problems. 
Based on the above, the purpose of this research is to understand the influence of mental health care technologies on PHC's daily practice, in order to identify gaps, weaknesses, potentialities to support discussions and to enable the formulation of strategies to implement a better professionals in this field, strengthening the interest in identifying, analyzing and proposing individual and collective actions that allow the rupture with the asylum model and the strengthening of a network constituted by open and territorial services.

In this sense, in view of the dimension and complexity of mental health, it is essential to articulate with $\mathrm{PHC}$, based on the principles of comprehensiveness and universality. Given this setting, the study has as guiding questions some questions: What technologies are used in Basic Care to care for users with mental disorders and how health care is being performed in Primary Health Care?

\section{OBJECTIVE}

To analyze the mental health care technologies used in the practices and processes that constitute Primary Health Care in the perspective of the nurse, since these professionals are in greater contact with the demands of the population and make up the coordination of health teams in PHC. We intend to put in a discussion agenda theoretical and practical elements in this writing about the weaknesses and potentialities experienced by nurses in the field of mental health.

\section{METHOD}

\section{Ethical aspects}

Ethical aspects were respected, according to Resolution 466/2012 of the National Health Council/Ministry of Health (Conselho Nacional de Saúde/Ministério da Saúde), which addresses research involving human subjects and was approved by the Ethics Committee ${ }^{(18)}$. The professionals who agreed to participate in the study signed the Informed Consent Form, which ensures the anonymity of the participants, and authorizes the use and publication of the data obtained.

\section{Theoretical and methodological framework}

It was based on the methodological composition between hermeneutics and dialectics, seeking the synthesis of the comprehending and critical processes, considering that the same reason that understands, clarifies and gathers, also contests, dissociates and criticizes Minayo ${ }^{(19)}$. For the analysis of the collected material, we used the analytical flowchart of Minayo ${ }^{(19)}$, adapted by Assis and Jorge ${ }^{(20)}$.

\section{Type of study}

This is a qualitative research within a critical and reflective perspective, because it allows the understanding of the social phenomenon and its relations in the field of health. For Minayo ${ }^{(19)}$, this type of study contemplates a universe of meanings, motives, beliefs, values and attitudes that correspond to a deeper space of relationships, processes and phenomena that cannot be restricted to the measurement of variables. In addition to making it possible to uncover social processes that are still little known, it allows the construction of new approaches and concept building during research.

\section{Study setting}

The study was developed in the city of Fortaleza, Ceará state, which is administratively organized in six Coordenações Regionais em Saúde (Regional Health Coordination-CORES) (I, II, III, IV, V and VI). The choice for this study delimited the participation of three units of Primary Health Care.

\section{Data source}

It counted on the participation of six nurses, thus distributed: two in CORES II; two in the IV and two in the V. The participation of the nurses was linked to the pre-established selection criteria, where they selected professionals with at least one year of performance in the Family Health Strategy. To do so, the number of interviews was defined by the process of deepening the objectives of the study and the issues under analysis, that is, when the collected interviews made it possible to deepen the study object, data collection was closed.

\section{Collection and data organization}

The data collection took place from April to May 2017, through free observation and semi-structured interviews. This collection technique addresses questions that allow the obtaining of subjective and objective information, allowing the informant to develop a rich and in depth discourse about the research theme.

The data were collected in two moments: in the first, a visit was made at the health unit, and a free observation was made to obtain a better understanding of the context of the research, besides identifying the availability of the professionals. In the second moment, the interviews with the nurses in the primary health care units, which were triggered by the following questions: What technologies are used in Basic Care to care for users with mental disorders and how health care is being performed in Primary Health Care?

To organize the information, three steps were proposed by Minayo $^{(19)}$ (1999) and retranslated by Assis and Jorge ${ }^{(20)}$ : ordering, classification and final analysis of the data. These phases are interrelated, dynamic and intercomplementary. Data ordering involves transcribing interviews, reading empirical material, and organizing data into different sets. The classification of data allows the construction of empirical data and, finally, the final analysis of data that emphasizes the meeting of the specificity of the object by the test of the lived with the essential relations that are established in the real conditions and in the private and social action.

\section{Data analysis}

The final analysis followed Minayo's hermeneutic and dialectics $^{(19,21-22)}$ and Assis and Jorge ${ }^{(20)}$, where it was possible to establish the complementarities, convergences, divergences and the unusual of the empirical material learned.

\section{RESULTS}

Based on the nurses' discourses, two essential analytical categories emerged: "Health technologies used in PHC for the care of users with psychological distress" and "To stop medicating suffering and to Train professionals". 
Health technologies used in Primary Health Care for the care of users with psychological distress

Here we present the speeches obtained, together with the professionals, about the mental health care technologies used during Primary Health Care (PHC) care. These technologies, in turn, are related to the subjective dimension, from a complex process in which new experiences, new relationships and diverse situations to be faced are observed, constituting a tangle of fragilities, potentialities, contradictions, agreement and challenges.

When they are led to reflect on the technologies of mental health care used in PHC, the discourses converge in the perspective of the reception as a practice that establishes a relation of the professionals with the user and facilitates the understanding of the individuality through the dialogue and listening qualified, according to the following speeches:

[...] Among the technologies used in basic care, we can mention the reception, which is done at the entrance of the health center, where we, nurses, talked with the users to better understand their problem and what brought them here. (Nurse 06)

[...] Among the technologies of mental health care, the only one we use here is the hosting, where we have contact with the user and he/she describes his/her problem. And then we refer to CAPS or to renew the prescription. (Nurse 03)

Another care technology described by nurses is matrixing in health. Through this technology, the PHC-produced mental health practices can become reflective, resourceful and resource-based.

Care technologies used in mental health here in the unit in which I work is the matrixing, which is a very important tool for family health. It facilitated the referral in the network, because I know everything, we have a group in whatsapp, when I have doubts I use the information technologies on my favor, and this facilitated much the care. [...] Because before, they came in the reception, only to renew the prescription, and to take the medications, were not followed-up, and today the situation changed. (Nurse 03)

However, although some nurses use mild mental health care technologies through the participation of innovative practices, the fragility and punctuality of these actions still persists for a limited number of professionals.

\section{To stop medicating suffering and to Train professionals}

Mental health care performed by nurses is limited by reductionist actions, such as the medicamentation of the subject, where there is renew of recipes without a criteria, and erroneous referrals to the CAPS, as can be seen in the following reports:

[...] In this unit there is no mental health work, we only renew the prescription, the patient comes from the CAPS, where he/ she has the initial prescription, and here we only renew, then they return to CAPS as the doctor says. (Nurse 05)

[...] Today, at the health center only works the general clinical scheduling, there is the day that he assists, and the patients are scheduled to renew the prescription, to make the appointment, and only. (Nurse 04)
[...] Our care today, within mental health, is unfocused. (Nurse 01)

Indeed, it is observed in the discourses of nurses working in Primary Health Care, the belief that problem-solving in cases of mental health is restricted to actions involving the use of medications, in order to treat the symptoms:

When a patient arrives with anxiety, with some kind of disorder, we try to refer them to a doctor, then he/she prescribed medication and they can treat the symptoms that the patient is presenting at the moment. (Nurse 02)

Our health center receives lots of medication, and all controlled medication is in this unit. Here, medication is rarely lacking. Even those who arrive in crisis, here we have medications to do in the outpatient, as injectable ones, tablets, that serves to mild the patient's symptoms. (Nurse 01)

When the patient is in crisis, is referred to the doctor's appointment, and is already medicated in the unit. (Nurse 05)

The speeches reveal the lack of capacity of most professionals to watch with safety and quality the users with mental disorders, due to the superficial knowledge on this subject. However, only one nurse revealed that she participated in training on mental disorders, and therefore felt able to assist such users. The following reports portray the questioning on the professional training of the participants:

[...] It has been a long time since it has been trained for mental health, and it is necessary because we feel insecure of worsening the patient's condition. (Nurse 04)

We have a schedule available for permanent education, but they don't offer the courses, people have to search for, and at the end we look for what we are closer to, and some important subjects such as mental health are not seen, at least for me. (Nurse 05)

I did the course, which is part of the permanent education and I feel able to assist people with mental disorders. (Nurse 02)

Another point evidenced in the nurses' speeches is the unnecessary referrals to the CAPS, which results in the saturation of the specialized services and are results of the PHC's lack of solvency, as we can identify in the speeches:

[...] Mental health patient arrives at the reception; the doctor starts with the first appointment, if the patient needs to be referred to CAPS. (Nurse 01)

[...] Patients with mental disorders are identified in the same host and are referred to the CAPS. (Nurse 05)

In this context, referrals need to have defined criteria to organize the flow of users in the psychosocial care network.

\section{DISCUSSION}

The results presented in this article show that the host is one of the technologies used with the users with psychological distress. Reception practices incorporate relational strategies 
that are important for establishing dialogue and understanding the problem of the subject, which makes it possible to promote qualified care, thus fostering the building of bonds and trust between health professionals and users, and a greater satisfaction perceived of the care offered. However, one should not only consider reception as a technology of extended care, which includes other essential elements, such as resolution, coresponsibility and comprehensiveness. In this sense, welcoming implies valuing the life history of each being involved, revealing an act of mutual interpretation between what the service can offer and what the user wants in their daily lives. Comprehensive action is further strengthened by the multiplicity of views on each situation and practices for health work ${ }^{(16)}$.

Another care technology described by nurses is matrixing in health. Thus, matrix support indicates a horizontal relationship, without authority, based on dialogic procedures, and is developed through the exchange of knowledge, the provision of guidelines, joint interventions and complementary interventions carried out by the supporter, but always considering the team of responsible case, although specialized support is needed at different times ${ }^{(23)}$.

The understanding of the nurses' change of attitude to perform the matrix support in the $\mathrm{PHC}$ reveals the need to expand the therapeutic offerings of the teams with psychosocial tools, as well as the capacity of health professionals to disseminate actions in mental health, aiming to build flows and therapeutic projects more effective with other health network services.

In the national territory, the Family Health Support Center (NASF), as a support team, offers a specialized back up in the Family Health Strategy (FHS) and uses matrix support as the main strategy for the development of the work. Brazilian studies portray positive results regarding care for people with psychological distress after implementation of the NASF, among which, the reduction of referrals to the CAPS and the construction of collective spaces of reflection among the different professionals ${ }^{(24-25)}$.

Some authors share reflections on the implementation of matrix support. Hirdes 13 considers it a very important tool for handling mental health situations in primary care, where joint care is defined by team professionals, enriching and sharing learning. Jorge, Sousa and Franco ${ }^{(26)}$ portray that the matrix support facilitates the encounter with the other and with the field of mental health, providing a space rich in possibilities, where issues not once perceived by $\mathrm{PHC}$ professionals, for various reasons, such as fear and stigmas related to the demand for mental health now become, under a new and expanded look, part of the need for health and comprehensive care to the user.

However, although the practices introduced in the care of the person suffering from psychological distress are important and innovative, and despite the increase in the provision of Primary Health Care services to mental health users, the organization of the work process is still based on the use and prevalence of the technologies (tools and specialized knowledge) to the detriment of relational technologies. This aspect is essential, because despite the effort to change care practices, the workers did not incorporate what proposes the psychiatric reform to their daily practice ${ }^{(27)}$.

Mental health in Primary Care involves more than care for mental disorders, requires the construction of comprehensive care models that address the user, their family and the community in general, and the formation of real and continuous links between professionals and users, expanding the possibilities of developing autonomy, self-esteem, self-care and guarantee of citizenship. It also involves support and care for the emotional suffering of the population, regardless of its intensity and clinical priority at the moment, within the contexts of each person's life ${ }^{(28)}$.

Nurses' reports indicate that practices aimed at renewing medical prescriptions persist. This practice in Primary Health Care favors the indiscriminate use of medications, without reflections on the true need for its use by the user. For Alencar, Cavalcante and Alencar ${ }^{(29)}$, little or nothing is done in relation to the renewal of prescriptions and the use of medicines for these users who, due to their peculiarities and subjectivities inherent to the process of mental illness, may present different limitations for the correct use of them.

Bezerra et al. ${ }^{(30)}$ affirm that the medicamentation refers to the control of biomedical practices on the life of the people, where the use of prescription and the use of medicines is seen as the only possible alternative to respond to the confrontation of psychic illnesses. In this sense, everyday situations experienced in life, such as anguish, mourning, malaise or other difficulties, which were understood as part of the subject's complexity and subjectivity, were considered to be diagnosable diseases or disorders, consequently "medicated" in search for healing ${ }^{(31)}$.

In this context, it is evident that psychosocial care is seen by some professionals as a tight and closed practice in the medicalmedicine-centered care model. However, it is necessary for practitioners to rethink their practice, whether individual or collective, because this reflection culminates in the recognition of fragilities, potentialities, needs, demands, problems and possibilities ${ }^{(29)}$.

These reports emphasize and reinforce the thesis that the mental health care practiced in primary care is still based on medication, that is, on the magical power of healing from medications to face personal, family and work problems ${ }^{(27,31)}$. This process results from chronological actions in the health services, revealed by the individualized and fragmented practices, as well as the lack of knowledge of professionals regarding subjective complaints and symptoms of users. Santos ${ }^{(32)}$ corroborates this line and observes the abusive indication of medications for psychological distress, often related to social and economic problems.

Frateschi and Cardoso $^{(33)}$ consider the medicalization of people with psychological distress as the product of a medicalhegemonic model with reduction of the individual to its biological aspect, based on technical procedures, centered on healing and hierarchy of knowledge, which distances the professional of the user, as a person in distress. Cavalcante et al. ${ }^{(34)}$ point out that the medicalization and the biologization of the being is explained by the lack of involvement of the team in seeking subsidies to include the subjects with some psychic pathology, in an comprehensive way, in the work process of the services, which causes the loss of the social/spiritual/cultural aspects of the man in distinction to the pathological/curative feature.

Costa, Celino, and Coura ${ }^{(35)}$ add that these crystallized practices in PHC's work process, influenced by the biomedical-positivist paradigm, make it difficult for people with mental disorders to care. The actions developed in Primary Care should be based 
on the logic of health promotion, disease prevention, diagnosis, treatment and rehabilitation. However, what is observed with the professionals' discourses is the predominance of the logic of the disease, with emphasis on medical knowledge, to the detriment of the user's life history, identifying the real needs of the patient.

On the other hand, Reis da Silva et al. ${ }^{(36)}$ affirm that this process is a result of the lack of training/qualification of the workers in dealing with the psychological distress, due to the lack of investment in the training.

In this study, the professionals of the FHS teams reveal the reduced participation in programs of Permanent Education in mental health, favoring the practices centered on the disease that fragments the subject.

Discussions brought through Campos Júnior and Amarante ${ }^{(37)}$ have identified that most professionals do not feel safe to deal with mental health situations. Therefore, the lack of contact with the theoretical framework seems to have the effect of not advancing some available forms of care, where the lack of capacity of the teams to deal with mental health problems makes it impossible to carry out effective interventions and makes the demand does not find a qualified listener ${ }^{(12,28)}$. The training of the professionals, the lack of knowledge and insufficient training to deal with cases of mental disorders are related to the lack of mental health practices in Primary Care ${ }^{(26)}$.

Thus, for Mental Health actions to be developed in Primary Health Care, it is fundamental to train these teams through permanent activities of discussion of cases with mental health teams, allowing care strategies that consider the multiple determinations of the health process and support the overcoming of the medication environment in the care of people with mental disorders. This lack of training of nurses to deal with problems related to mental health favors practice based on biomedical knowledge, directing patients to specialized care without using criteria.

For Quinderé et al. ${ }^{(38)}$, the lack of training and creation of tools to intervene in mental health often leads to a precipitating referral of these patients to the Psychosocial Care Center (CAPS). Lucchese et al. ${ }^{(39)}$ corroborate and affirm that in the face of the difficulty related to the lack of knowledge of PHC professionals, it is common to refer to specialized services, generating unnecessary overhead and elevation in these services.

The data obtained indicate that the professionals perform referrals, sometimes unnecessary, to the CAPS as a form of care. Campos Júnior and Amarante ${ }^{(37)}$ affirm that the relationship between Family Health Strategy and Mental Health comes through referrals to specialties, due to the insecurity of the vast majority of professionals to deal with mental health situations. Cavalcante et al. ${ }^{(34)}$ show that when referring to the CAPS as a care strategy or a health action carried out in isolation to this part of the population, the responsibility and the resolution of the FHS with the responsibility and the resolution of the FHS with the health problems of the population are disregarded.

These unnecessary referrals saturate the specialized services and are the result of PHC's lack of resolvability, and it is important to increase the investment and expansion of Permanent Education for Primary Care professionals, so that they develop skills in dealing with people with mental disorders, strengthening the role of the PHC in order to meet the real needs of the population. There is a need for FHS professionals to assume a central role in comprehensive mental health care, making local primary care units not only diagnostic and referral, but also offerings of resolute care and joint responsibility for mental health.

\section{Study limitations}

The limitations of this study are the participation of nurses only, and it is necessary to include other health professionals for a general understanding of the phenomenon. However, these limitations did not compromise the quality of the data obtained.

\section{Contributions to the Nursing}

The data obtained by this study made it possible to understand the gaps in the care practices performed by nurses, with the users with psychological distress, enabling them to rethink strategies for the implementation of individual and collective actions that allow the transversality of care.

\section{FINAL CONSIDERATIONS}

The use of care technologies in mental health practices is innovative; However, in order for the insertion of these technologies into the daily life of health professionals, a movement is required to transform the model of mental health care, which requires the epistemological review and the reflection of health professionals in the work process in the context of mental health care, as a way of consolidating new care practices.

The challenges presented for the implementation of these innovative practices are limited to actions in mental health care, such as the renewal of revenues and medicalization of users; to fragmentation of care; weakness in the matrix process; the insufficient knowledge of professionals to assist mental health users, the lack of training of mental health professionals and the production of practices based on biomedical knowledge. In fact, what is seen in the health services is a reduced therapy to psychotropic drugs, with fragile communication between professionals and users and little use of soft and hard technologies.

The study pointed to the reception and matrixing as the main care technologies exercised in the interface of Primary Health Care with Mental Health, however, need to be strengthened and expanded so that comprehensive care is sought. The use of these technologies in mental health allows the construction of a longitudinal care, multidimensional considering the subjectivity of the subject.

Given this context, it is a challenge to introduce unique and collective care practices capable of promoting quality mental health care that goes beyond scientific knowledge, including building strong relationships with users and the community, needs.

Other practices that also need to be incorporated in the daily services are the use of relational technologies and the strengthening of links with users, as they produce a path capable of dealing with the singularities of individuals. In addition, it is necessary to invest in the qualification of $\mathrm{PHC}$ professionals to promote action based on the care practices in the field of mental health.

This article raises new studies that aim to reflect on effective strategies to overcome the challenges presented and to re-signify the professional practices in SUS. 


\section{REFERENCES}

1. Brasil. Ministério da Saúde. Secretaria de Atenção à Saúde. Departamento de Atenção Básica. Diretrizes do NASF: Núcleo de Apoio a Saúde da Família. Brasília: Ministério da Saúde; 2010.

2. Organização Mundial da Saúde - OMS. Integrating mental health into primary care: a global perspective. Geneva: WHO/WONCA; 2008.

3. Muniz MP, Abrahão AL, Souza AC, Tavares CMM, Cedro LF, Storani M. Ampliando a rede: quando o usuário de drogas acessa a atenção psicossocial pela atenção básica. Rev Pesqui Cuid Fundam[Internet]. 2015[cited 2017 Jun 19];7(4):3442-53. Available from: http://www.seer.unirio.br/index.php/cuidadofundamental/article/viewFile/4951/pdf_1734

4. Minozzo F, Costa II. Apoio matricial em saúde mental entre CAPS e Saúde da Família: trilhando caminhos possíveis. PsicoUSF[Internet]. 2013[cited 2017 Jun 19]; 18(1):151-60. Available from: http://www.scielo.br/pdf/pusf/v18n1/v18n1a16.pdf

5. Silva RC, Ferreira MA. A tecnologia em saúde: uma perspectiva psicossociológica. Esc Anna Nery Rev Enferm[Internet]. 2009[cited 2017 Jun 19];3(1):169-73. Available from: http://www.scielo.br/pdf/ean/v13n1/v13n1a23.pdf

6. Brasil. Ministério da Saúde. Secretaria de Ciência, Tecnologia e Insumos Estratégicos. Departamento de Ciência e Tecnologia. Política Nacional de Gestão de Tecnologias em Saúde. Brasília: Ministério da Saúde; 2010.

7. Merhy EE, Feuerwerker LCM. Novo olhar sobre as tecnologias de saúde: uma necessidade contemporânea. In: Mandarino ACS, Gomberg E, (Orgs.). Leituras de novas tecnologias e saúde. São Cristóvão: Editora UFS; 2009. p.29-74.

8. Coelho MO, Jorge MSB. Tecnologia das relações como dispositivo do atendimento humanizado na atenção básica à saúde na perspectiva do acesso, do acolhimento e do vínculo. Ciênc Saúde Colet[Internet]. 2009[cited 2017 Jun 19];14(Suppl-1):1523-31. Available from: http://www.scielo.br/pdf/csc/v14s1/a26v14s1.pdf

9. Merhy EE. Em busca do tempo perdido: a micropolítica do trabalho vivo em saúde. In: Merhy EE, CRO, (Orgs.). Agir em saúde: um desafio para o público. São Paulo: Hucitec; 1997. p. 71-112.

10. Olfson M. The rise of primary care physicians in the provision of US Mental Health Care. J Health Polit Policy Law [Internet]. 2016[cited 2017 Jun 19];41(4):559-83. Available from: https://doi.org/10.1215/03616878-3620821

11. Ruud T, Aarre TF, Boeskov B, Husvåg PS, Klepp R, Kristiansen SA, et al. Erratum to: Satisfaction with primary care and mental health care among individuals with severe mental illness in a rural area: a seven-year follow-up study of a clinical cohort. Int J Ment Health Syst[Internet]. 2016[cited 2017 Jun 19];10(40). Available from: https://www.ncbi.nlm.nih.gov/pmc/articles/pmid/27186237/

12. Frosi RV, Tesser CD. Mental health care practices in primary health care: an analysis based on experiences developed in Florianópolis, Brazil. Ciênc Saúde Colet[Internet]. 2015[cited 2017 Jun 19];20(10):3151-61. Available from: http://www.scielo.br/pdf/csc/v20n10/ en_1413-8123-csc-20-10-3151.pdf

13. Hirdes A. A perspectiva dos profissionais da Atenção Primária à Saúde sobre o apoio matricial em saúde mental. Ciênc Saúde Colet[Internet]. 2015[cited 2017 Jun 19];20(2):371-82. Available from: http://www.scielo.br/pdf/csc/v20n2/1413-8123-csc-20-02-0371.pdf

14. Campos RO, Gama CA, Ferrer AL, Santos DVD, Stefanello S, Trapé TL, et al. Saúde mental na atenção primária à saúde: estudo avaliativo em uma grande cidade brasileira. Ciênc Saúde Colet[Internet]. 2011 [cited 2017 Jun 19];16(12):4643-52. Available from: http://www.scielo.br/pdf/csc/v16n12/13.pdf

15. Hirdes A, Scarparo HBK. The maze and the minotaur: mental health in primary health care. Ciênc Saúde Colet[Internet]. 2015[cited 2017 Jun 19];20(2):383-93. Available from: http://www.scielo.br/pdf/csc/v20n2/en_1413-8123-csc-20-02-0383.pdf

16. Jorge MSB, Pinto DM, Quinderé PHD, Pinto AGA, Sousa FSP, Cavalcante CM. Promoção da Saúde Mental - Tecnologias do Cuidado: vínculo, acolhimento, co-responsabilização e autonomia. Ciênc Saúde Colet[Internet]. 2011[cited 2017 Jun 19];16(7):3051-60. http://www.scielo.br/scielo.php?script=sci_arttext\&pid =S1413-81232011000800005\&lng = en

17. Campos RTO, Furtado JP, Passos E, Ferrer AL, Miranda L, Gama CAP. Avaliação da rede de centros de atenção psicossocial: entre a saúde coletiva e a saúde mental. Rev Saúde Pública[Internet]. 2009[cited 2017 Jun 19];43(Suppl-1):16-22. Available from: http:// www.scielo.br/pdf/csc/v16n7/05.pdf

18. Brasil. Conselho Nacional de Saúde. Comissão Nacional de Ética em Pesquisa - CONESP. Normas para pesquisas envolvendo seres humanos. Resolução CNS 466. Serie Cadernos Técnicos. Brasília: Ministério da Saúde, 2012.

19. Minayo MC. Pesquisa social: teoria, método e criatividade. 14a ed. Petrópolis: Vozes; 1999.

20. Assis MMA, Jorge MSB. Métodos de análise em pesquisa qualitativa. In: Santana JSS, Nascimento MAA, (Orgs.). Pesquisa: métodos e técnicas de conhecimento da realidade social. Feira de Santana: UEFS Editora; 2010.

21. Minayo MC, (Org.). Pesquisa Social: Teoria, método e criatividade. 29a ed. Petrópolis, Rio de Janeiro: Editora Vozes; 2010.

22. Minayo MC. O desafio do conhecimento: pesquisa qualitativa em saúde. 11a ed. São Paulo: Hucitec; 2008.

23. Pegoraro RF, Cassimiro TJL, Leão NC. Matrix support in mental health according to the professionals of the Family Health Strategy. Psicol Est[Internet]. 2014[cited 2017 Jun 19];19(4):621-31. Available from: http://www.scielo.br/pdf/pe/v19n4/en_1413-7372pe-19-04-00621.pdf 
24. Barros JO, Gonçalves RMA, Kaltner RP, Lancman S. Matrix support strategies: the experience of two Family Health Support Centers (NASFs) in São Paulo, Brazil. Ciênc Saúde Colet[Internet]. 2015[cited 2017 Jun 19];20(9):2847-56. Available from: http://www. scielo.br/pdf/csc/v20n9/en_1413-8123-csc-20-09-2847.pdf

25. Machado DKS, Camatta MW. Support matrix as a tool for coordination between Mental Health and Primary Health Care. Cad Saúde Colet[Internet]. 2013[cited 2017 Jun 19];21(2):224-32. Available from: http://www.scielo.br/pdf/cadsc/v21n2/18.pdf

26. Jorge MSB, Sousa FSP, Franco TB. Apoio matricial: dispositivo para resolução de casos clínicos de saúde mental na Atenção Primária à Saúde. Rev Bras Enferm[Internet]. 2013[cited 2017 Jun 19];66(5):738-744. Available from: http://www.scielo.br/pdf/ reben/v66n5/15.pdf

27. Vasconcelos MGF, Jorge MSB, Catrib AMF, Franco TB. Projeto terapêutico em Saúde Mental: práticas e processos nas dimensões constituintes da atenção psicossocial. Interface[Internet]. 2016[cited 2017 Jun 19];20(57):313-23. Available from: http://www. scielo.br/pdf/icse/v20n57/1807-5762-icse-20-57-0313.pdf

28. Alfena MD. Uso de psicotrópicos na atenção primária[Dissertação]. Escola Nacional de Saúde Pública Sergio Arouca, Rio de Janeiro, 2015. $68 \mathrm{f}$

29. Alencar TOS, Cavalcante EAB, Alencar BR. Assistência Farmacêutica e saúde mental no Sistema Único de Saúde. Rev Ciênc Farm Básica Ap. 2012[cited 2017 Jun 19];33(4):489-95.

30. Bezerra IC, Jorge MSB, Gondim APS, Lima LL, Vasconcelos MGF. "Fui lá no posto e o doutor me mandou foi pra cá": processo de medicamentalização e (des)caminhos para o cuidado em saúde mental na Atenção Primária. Interface[Internet]. 2014 [cited 2017 Jun 19];18(48):61-74. Available from: http://www.scielo.br/pdf/icse/v18n48/1807-5762-icse-18-48-0061.pdf

31. Brasil. Ministério da Saúde. Secretaria de Atenção à Saúde. Departamento de Atenção Básica. Saúde mental. Brasília: Ministério da Saúde; 2013.

32. Santos DVD. Uso de psicotrópicos na atenção primária no Distrito Sudoeste de Campinas e sua relação com os arranjos da clínica ampliada[Dissertação]. Programa de Pós-Graduação em Saúde Coletiva. Universidade Estadual de Campinas. Faculdade de Ciências Médicas; Campinas. 2009.

33. Frateschi MS, Cardoso CL. Saúde Mental na Atenção Primária à Saúde: avaliação sob a ótica dos usuários. Physis[Internet]. 2014[cited 2017 Jun 19];24(2):545-65. Available from: http://www.scielo.br/pdf/physis/v24n2/0103-7331-physis-24-02-00545.pdf

34. Cavalcante CM, Pinto DM, Carvalho AZT, Jorge MSB, Freitas CHA. Desafios do cuidado em saúde mental na estratégia saúde da família. RBPS[Internet]. 2011[cited 2017 Jun 19];24(2):102-8. Available from: http://periodicos.unifor.br/RBPS/article/view/2059

35. Costa GMC, Celino MC, Coura AS. Saúde-Doença Mental na atenção primária: uma prática assistencial em construção. Rev APS[Internet]. 2012[cited 2017 Jun 19];15(4). Available from: http://www.scielo.br/pdf/csc/v14n1/a19v14n1.pdf

36. Silva GR, Reis HFT, Santos EM, Souza MPA, Azevedo RL. Saúde Mental na Atenção Primária à Saúde: percepções da equipe de saúde da família. Cogitare Enferm[Internet]. 2016[cited 2017 Jun 19];21(2):01-08. Available from: https://revistas.ufpr.br/cogitare/ article/view/43861

37. Campos Jr A, Amarante PDC. Estudo sobre práticas de cuidado em saúde mental na Atenção Primária: o caso de um município do interior do estado do Rio de Janeiro. Cad Saúde Colet[Internet]. 2015[cited 2017 Jun 19];23(4):425-35. Available from: http:// www.scielo.br/pdf/cadsc/v23n4/1414-462X-cadsc-23-4-425.pdf

38. Quinderé PHD, Jorge MSB, Nogueira MSL, Costa LFA, Vasconcelos MGF. Acessibilidade e resolubilidade da assistência em saúde mental: a experiência do apoio matricial. Ciênc Saúde Colet[Internet]. 2013[cited 2017 Jun 19];18(7):2157-66. Available from: http://www.scielo.br/pdf/csc/v18n7/31.pdf

39. Lucchese $R$, Castro $P, B a S$, Rosalem V, Silva $A$, Andrade M, et al. Saberes profissionais na atenção primária à saúde da pessoa/ família em sofrimento mental: perspectiva Le Boterf. Rev Esc Enferm USP[Internet]. 2014[cited 2017 Jun 19];48(Spe2):123-31. Available from: https://www.revistas.usp.br/reeusp/article/view/103117/101455 